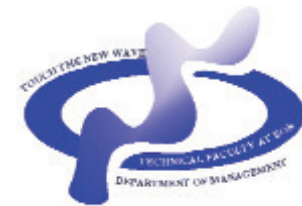

www.sjm06.com

\title{
INVESTMENT INNOVATION TRENDS: FACTOR-BASED INVESTING
}

\author{
Sanja Centineo ${ }^{*}$ and Santo Centineo $b$

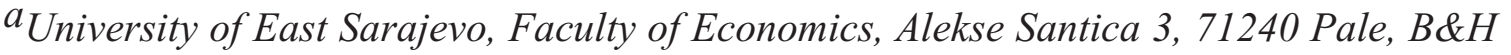

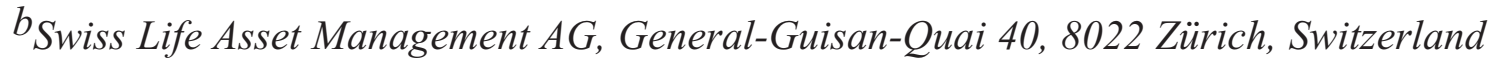

(Received 24 April 2016; accepted 17 October 2016)

\begin{abstract}
This article shows that it can take a long period of time until research knowledge finds its application in practice and get disseminated as innovation trend. Factor-based investing is such an example. Having its developing roots in the nineties, it took more than two decades until this approach was detected by the investment community. The goal of this article is to recall the definition of factor investing, present its historical evolvement and motivate its recent break-through and current trend among investment practitioners (known also under the notion smart beta). It aims at familiarizing with this investment approach from a practical perspective and highlighting its diversifying benefits in a portfolio context with the potential to outperform the market on riskadjusted basis.
\end{abstract}

Keywords: Smart beta, risk factors, market anomalies, diversification, outperformance

\section{INTRODUCTION}

Factor investing is increasingly in the spotlight. Financial magazines run features on it. Seminars are organized on this subject and investors consider adopting its approach. Yet, you might wonder is it just a hype? Is the increased interest in factor investing not more than a passing trend? This question demands an answer because investors are upon the hype. With this article we want to shed light on this investment trend which attracted that much attention from investment practitioners in recent years. This article provides a brief overview on what factor investing is, how it came about, what helped it to become that much popular to get manifested as innovation trend among

\footnotetext{
* Corresponding author: sanja.centineo@yahoo.com
}

DOI: $10.5937 /$ sjm12-10764 
investment practitioners. In addition, it highlights the rising importance of factorbased investing and the reasons of investors for applying this investment approach. Backtested analysis in this article shows that factor-based investments lead to superior (risk-adjusted) performance results compared to the pure stock market index. As the correlations between different risk factors are clearly below one, factor based investing provides diversifying benefits and exhibits significant advantages in a portfolio context.

\section{THE DEFINITION OF FACTOR INVESTING}

Factor investing is a systematic approach to investing strategically in certain parts of the financial markets which realize better returns over longer periods than those in other segments. Leading academic studies from the seventies onwards demonstrate that value, momentum, small cap and low volatility stocks, for example, systematically generate higher risk-adjusted returns than an arbitrary portfolio consisting of the world stock market index and a risk-free asset (see Figure 1).

\section{THE EVOLUTION OF FACTOR INVESTING}

How did the story of factor investing begin? The story starts in the 1970s when academic researchers began to challenge the prevailing assumptions of the Capital-AssetPricing-Model (CAPM) that was developed by William Sharpe (1964), John Lintner (1965a,b) and Jan Mossin (1966) in the early 1960s. This model envisions a fictitious world where markets are efficient and investors are rationale. It predicts a positive relationship between risk and return. In the 1960s academics approached asset pricing with normative theories. This makes sense since financial data and computational power were not readily available. At that time it was better to stick to financial theory where knowledge could not be acquired by means

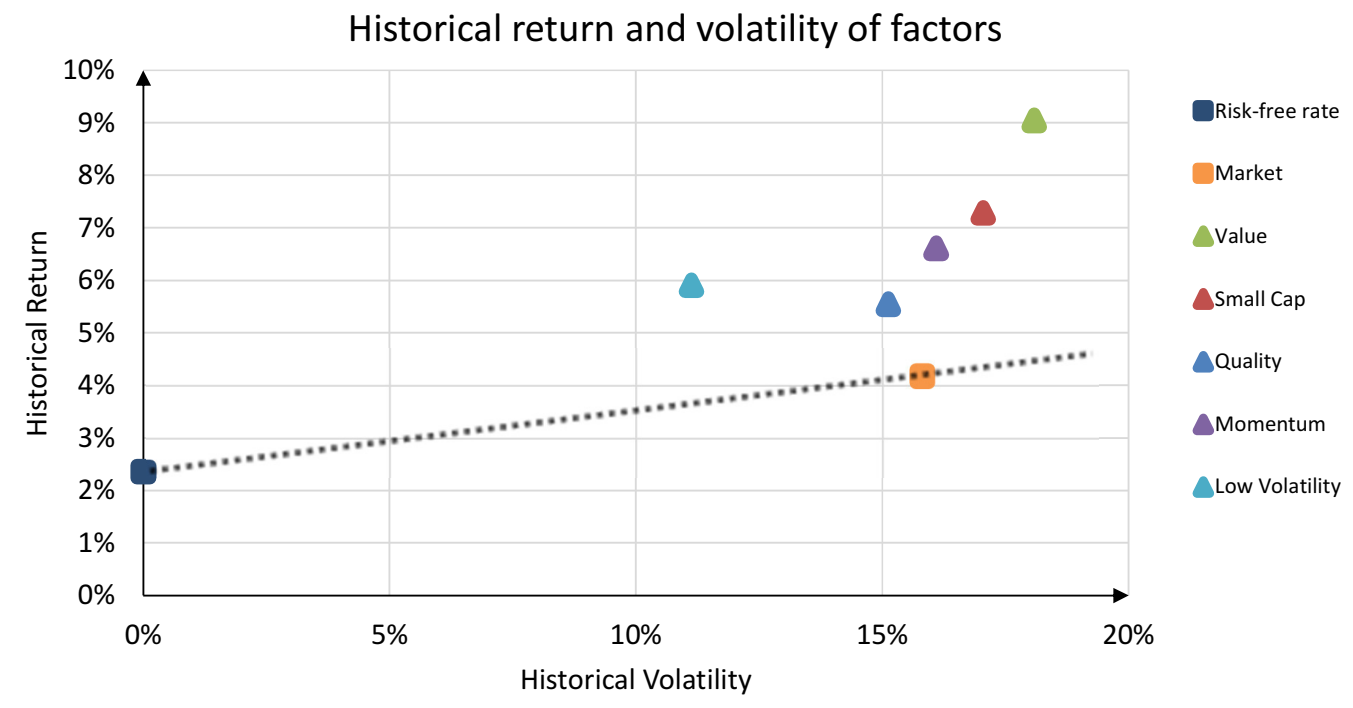

(Source: Bloomberg, own calculations)

Figure 1. Historical return and volatility of factors (31.12.1998-30.11.2015) 
of observation. This situation changed when better data and increasing computational power led the predominance of the empirical research. Academics gained a much better understanding of the pricing of stocks and other financial securities. For example, Robert Haugen and James Heins (1972; 1975) studied the returns of stocks and came to a surprising conclusion. The relationship between risk and return is not linear at all and contrary to the prevailing theory lowrisk stocks actually produced higher returns than one would expect. Haugen finally merged this further into low-volatility investing which became one of the building blocks of factor investing.

But others were also questioning the descriptive powers of the CAPM. Eugene Fama and Kenneth French studied the returns of different group of stocks in the 1990s. Their results showed that small cap and value stocks performed remarkably better than the prevailing model would lead you to expect. Their study (Fama \& French, 1992; 1993) proved that certain parts of the market can yield higher returns and that not all stock performance is explained by market risk but also by other factors.

A further building block for factor investing was added in the early nineties. Jegadeesh and Titman (1993) proved that past leaders on performance were also likely to be future winners. This phenomenon became later known as the momentum effect. Although the academic evidence started to demonstrate and prove that professional investors might benefit from extra returns or lower risk through factor investing, there was a burden on its implementation. Some investors started to tilt their portfolio to factors but high conviction to integrate these factors into the strategic allocation to factors still failed to happen. Their organizations were still focusing on asset classes in different regions. Implementing factor investing would therefore require organizational restructuring which in some cases could be quite challenging.

\section{THE BREAK-THROUGH OF FACTOR INVESTING}

The global financial crisis in 2008 provided an unexpected break-through. Norway would become the starting point of the revolution. The Norwegian Sovereign Wealth Fund was setup in 1990 and invests the country's oil and gas revenues in the financial markets to safeguard and build a sustainable financial wealth for the country's future generations. The fund's market value was 2'019 billion Norwegian Krone (371 billion US Dollar) at the end of 2007. ${ }^{1}$ In October 2008 just one month after the fall of Lehman Brothers the fund lost a substantial part of its value. The fund was reporting a performance of $-23 \%$ (in international currency) for that year, the weakest result in the fund's history. ${ }^{2}$ By investing in stocks and bonds across different regions, the fund was supposed to be well-diversified. Figure 2 shows the fund's benchmark composition for 2007.

Investigations have commenced to analyze the fund's performance. The investigation of the fund's performance was headed by three academics: Andrew Ang (Columbia Business School), William Goetzmann (Yale School of Management), and Stephen Schaefer (London Business Scholl). They found that the performance was largely explained by exposure to different factors - something that the fund was not aware of it at that time. ${ }^{3}$ The active portfolio suffered a large dramatic dip. Many

\footnotetext{
${ }^{1}$ See the website of Norges Bank Investment Management (http://www.nbim.no). At the end of 2014 the fund was managing 6’431 billion Norwegian Krone (859 billion US Dollar).

2 See the fund's annual report of 2008, available at http://www.nbim.no/en/transparency/reports/2011-and-older/2008/annual-report-2008/.

3 See Ang, Goetzmann and Schaefer (2009).
} 


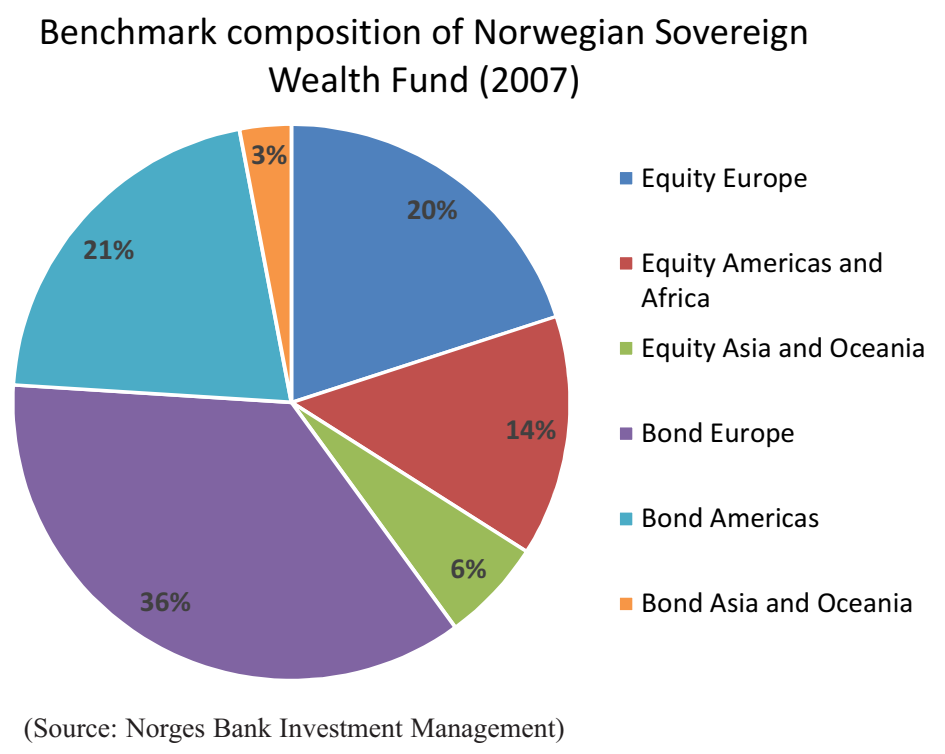

Figure 2. Benchmark composition of the Norwegian Sovereign Wealth Fund (2007)

different asset classes had exposure to the same factors. The portfolio was therefore not well-diversified at all. These three academics advised the Norwegian government to explicitly allocate to factors instead of assets and to pay more attention to factor risk. Professional investors around the world faced similar problems with diversification and were open to new approaches.

\section{FACTOR INVESTING ONLY A HYPE?}

To get back whether factor investing is just a hype. Although factor investing has gained ground only slowly over recent decades and the worldwide crisis was needed to boost the adoption process it can be observed that factor investing is increasingly in the spotlights. We strongly believe that factor investing is here to stay for three reasons: First, it builds on years of academic research that proves it works. Second, more and more empirical evidence on factors and market anomalies is discovered ${ }^{4}$ and being put into practice, and third, growing numbers of institutions and professional investors already allocate part of their portfolios to factor investing which is documented below in more detail.

\section{SMART BETA AS AN ALTERNATIVE NOTION FOR FACTOR INVESTING}

Smart beta is an alternative notion for factor investing which can be often read. It is mainly used among investment professionals and is more than just a marketing gimmick to boost the sale of factor-based investment funds. The meaning behind the smart beta subsumes the fact that factor investing as enhanced passive investing lies in between purely passively managed investments replicating a market index and its systematic risk - the so called beta ${ }^{5}$ - and the actively managed investment strategies that try to capture an outperformance versus the market - the so called alpha6.

\footnotetext{
${ }^{4}$ See Banz (1981) for size effect; Frazzini and Pedersen (2013) for low beta anomaly; Baker, Bradley and Wurgler (2011) for low volatility anomaly; Asness, Frazzini and Pedersen (2014) for quality anomaly and Lakonishok, Shleifer and Vishny (1994) for value effect.

5 See Sharpe (1964), Lintner (1965a,b) and Mossin (1966).

6 See Jensen (1968).
} 


\section{THE RISING IMPORTANCE OF FACTOR INVESTING}

For the second year in row, Market Strategies International, in collaboration with Invesco PowerShares, examined the growing smart beta exchange-traded funds (ETFs) trend in the institutional market. ${ }^{7}$ The results of the latest study reveal that smart beta ETFs have further penetrated the institutional market and are poised for additional growth moving forward. In 2014 investors added 240 billion US Dollar to US listed ETFs. There are more than 1.450 US listed ETFs with a collective assets under management of nearly 2 trillion US Dollar. Smart beta ETFs stand on the success of this larger ETF evolution and gain further momentum, particularly in the institutional market. Smart Beta ETFs accounted for over $17 \%$ of US ETFs net inflows in 2014. They saw a higher year-over-year increase in institutional usage than the original market cap index ETFs. Today there are more than 350 smart beta ETFs available in the US comprising over 230 billion US Dollar assets under management, up from 212 products and 64.8 billion US Dollar in 2010.

Many asset managers, banks and small investment boutiques provide advisory or direct investment opportunities to factor investing. The worldwide largest asset manager in terms of assets under management is BlackRock. The company managed 4.65 trillion US Dollar as per end of 2014.8 iShares represents the family of ETFs that is managed by BlackRock. Recently it launched five ETFs on factor investing with respect to the MSCI World stock universe: ${ }^{9}$

a. Momentum: Exposure to stocks exhibiting the strongest risk-adjusted performance over the last 6 and 12 months. b. Value: Exposure to stocks that are undervalued based on their fundamentals such as the company's earnings, cash flow ratios and equity's book value.

c. Size: Exposure to stocks with a smaller market capitalization.

d. Quality: Exposure to stocks with stable earnings and strong balance sheets (i.e. with high return on equity and low earnings variability and leverage).

e. Low Volatility: Exposure to an optimized portfolio of stocks with a reduced volatility compared to the market index itself.

Figure 3 shows the cumulative net inflows into these factor ETFs. We can see that the total assets of these funds (adjusted for market moves) are steadily increasing. There is a clear demand for factor investing by the investment community and the conviction that factor investing can improve the riskadjusted performance of the portfolio starts to spread among investment professionals. Especially the low volatility and quality ETFs seem to be very popular among investors. This is not surprising as investors are known to be risk-averse and these ETFs are characterized by a lower risk than the market (see Figure 1).

\section{PRIMARY REASONS OF INVESTORS FOR USING FACTOR- BASED INVESTMENTS}

The survey from MarketStrategies International mentioned above additionally reveals some information on investor's attitude towards factor-based ETFs. The primary reasons of institutional investors for using smart beta ETFs are performance/returns followed by reduced

\footnotetext{
7 See "The Evolution of Smart Beta ETFs", 2015, MarketStrategies International.

8 See company's ranking and assets under management in the survey conducted by Towers Watson ("The 500 largest asset managers", 2015, Towers Watson).

${ }^{9}$ Fund inception for momentum, value, size and quality ETF was in October 2014. Fund inception for low volatility ETF was in December 2012 (according to Bloomberg).
} 


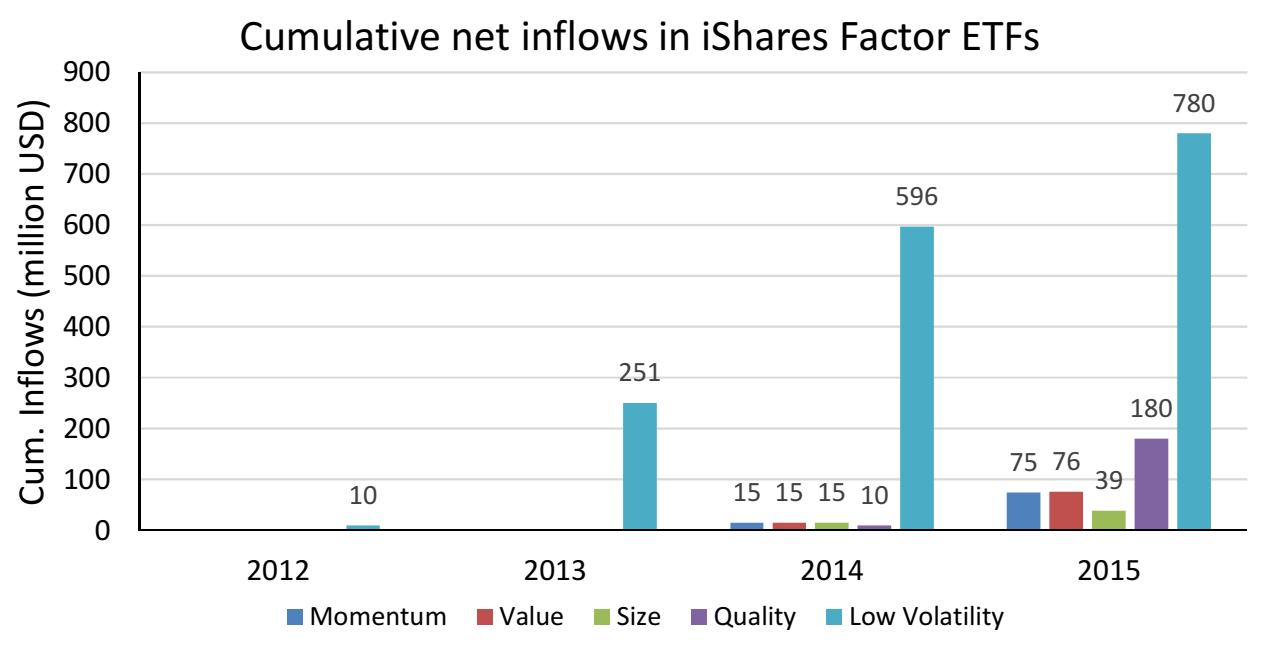

(Source: Bloomberg, own calculations)

Figure 3. Cumulative net inflows in iShares Factor ETFs

volatility and access to specific assets (see Figure 4). Lack of familiarity and short track record are mentioned as reasons why some investors still refrain from it. However, this skepticism should vanish over time once the investors are getting more confident with this new investment opportunities and once these funds have established a longer performance track record.

Following the trend, the usage of smart beta ETFs is slated to outpace growth in all other types of ETFs. According to the survey conducted by MarketStrategies International, 62 percent of institutional investors expect to increase their use of smart beta ETFs in the next three years (see Figure 5).
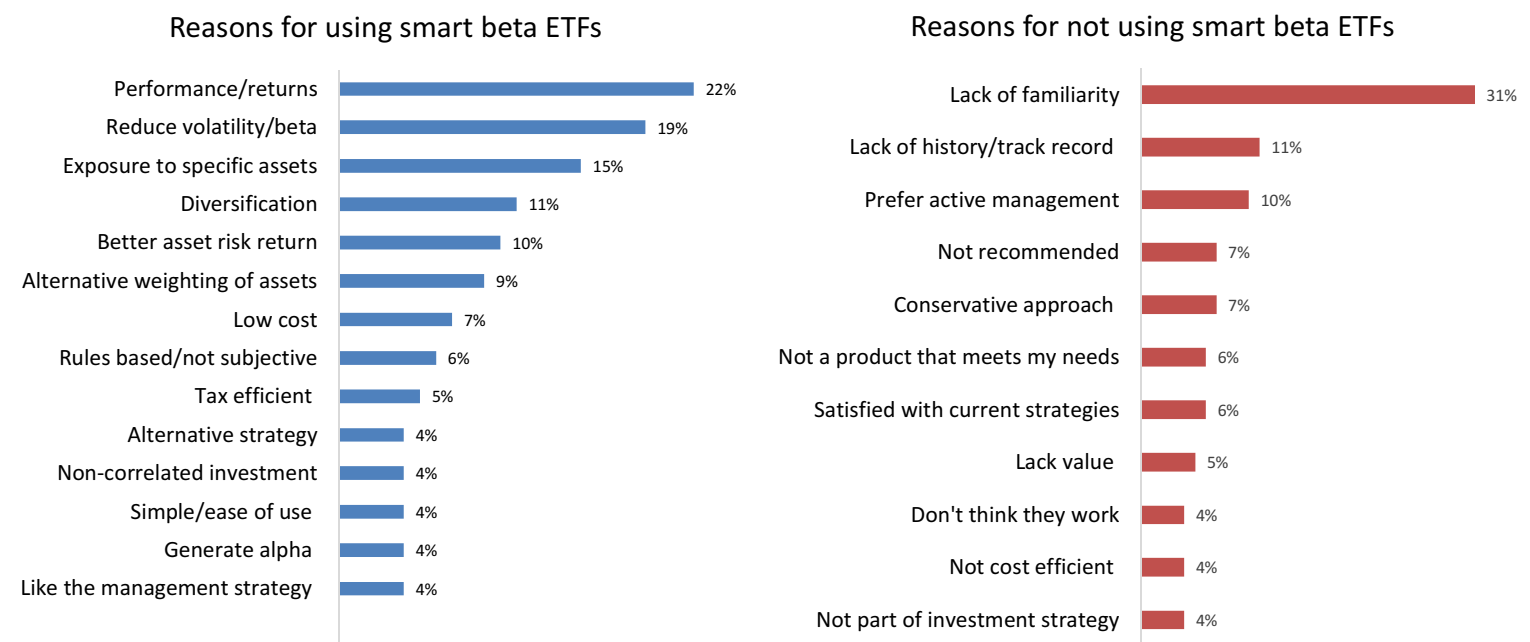

(Source: MarketStrategies International)

Figure 4. Reasons of investors for (not) using smart beta ETFs 


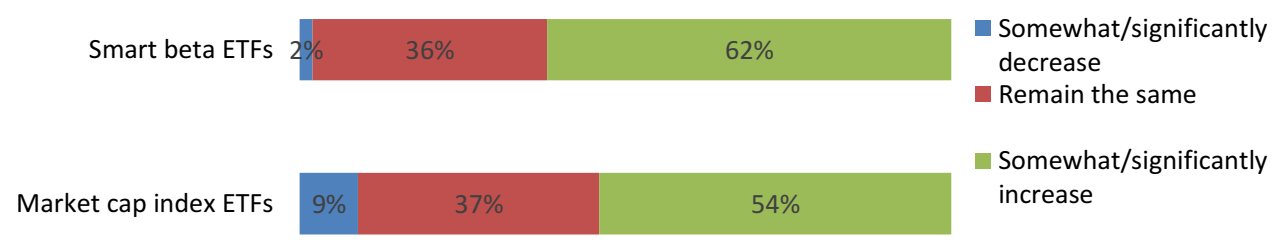

(Source: MarketStrategies International)

Figure 5. Expected change of the smart beta ETF usage in the next three years

\section{RETURN CYCLICALITY AND SOME EMPIRICAL RESULTS ON FACTOR INVESTING}

If we compare the performance between the different risk factors, we can observe that there is no clear winner with a steady outperformance over the long-run. The best factor performers are alternating depending on the underlying market regime (see Figure 6). During bull market periods the factors momentum, size and value are supposed to perform better whereas in bear market periods the factors low volatility and quality seem to be superior. Glushkow (2015) shows that it is difficult to time the factors and that systematic rule-based rebalancing of factors respectively a dynamic factor allocation does not provide statistically significant superior returns than a static factor exposure.
However, we can observe in Figure 6 that factor returns behave differently over time indicating that the factors are characterized by a relatively low correlation to each other which is even more pronounced during bear market periods highlighting their diversifying benefits in a portfolio context (see Figure 7).

A well-diversified (buy-and-hold) portfolio of (at beginning) equal weighted factor exposures to momentum, value, small cap, quality and low volatility has consistently outperformed the market (see Figure 8). The annualized outperformance amounts to 2.5 percent. The excess returns of the portfolio versus the market are almost steady over the entire time period. The relative performance index exhibits no severe drawdowns. The volatility of the excess returns (also defined as tracking

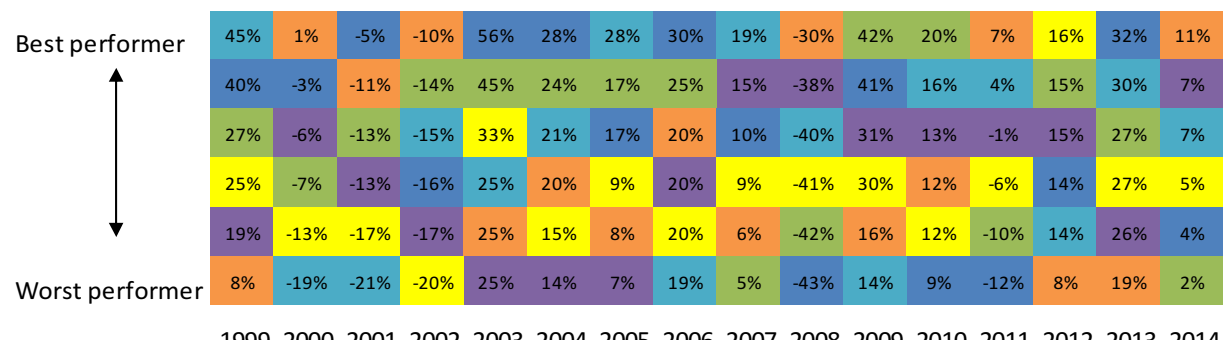

(Source: Bloomberg, own calculations)
Value

Size

Quality

Momentum

Low Volatility

Market

Figure 6. Yearly performance of different factors from 1999-2014 


\begin{tabular}{r|ccccc}
$\begin{array}{c}\text { Correlation } \\
\text { (Entire Period) }\end{array}$ & Value & Size & Quality & Momentum & Low volatility \\
\hline Value & 1.00 & 0.95 & 0.91 & 0.81 & 0.87 \\
\cline { 2 - 5 } Size & & 1.00 & 0.91 & 0.84 & 0.87 \\
\cline { 3 - 5 } Quality & & & 1.00 & 0.84 & 0.90 \\
\cline { 3 - 5 } Momentum & & & & 1.00 & 0.77 \\
\cline { 3 - 5 } Low volatility & & & & & 1.00
\end{tabular}

\begin{tabular}{r|ccccc}
$\begin{array}{c}\text { Correlation } \\
\text { (Bear Market) }\end{array}$ & Value & Size & Quality & Momentum & Low volatility \\
\hline Value & 1.00 & 0.93 & 0.89 & 0.77 & 0.87 \\
\cline { 2 - 5 } Size & & 1.00 & 0.89 & 0.82 & 0.85 \\
\cline { 2 - 5 } Quality & & & 1.00 & 0.87 & 0.90 \\
\cline { 3 - 5 } Momentum & & & & 1.00 & 0.70 \\
\cline { 3 - 5 } Low volatility & & & & & 1.00
\end{tabular}

(Source: Bloomberg, own calculations)

Figure 7. Correlation of monthly returns between factors (from 31.12.1998-30.11.2015)

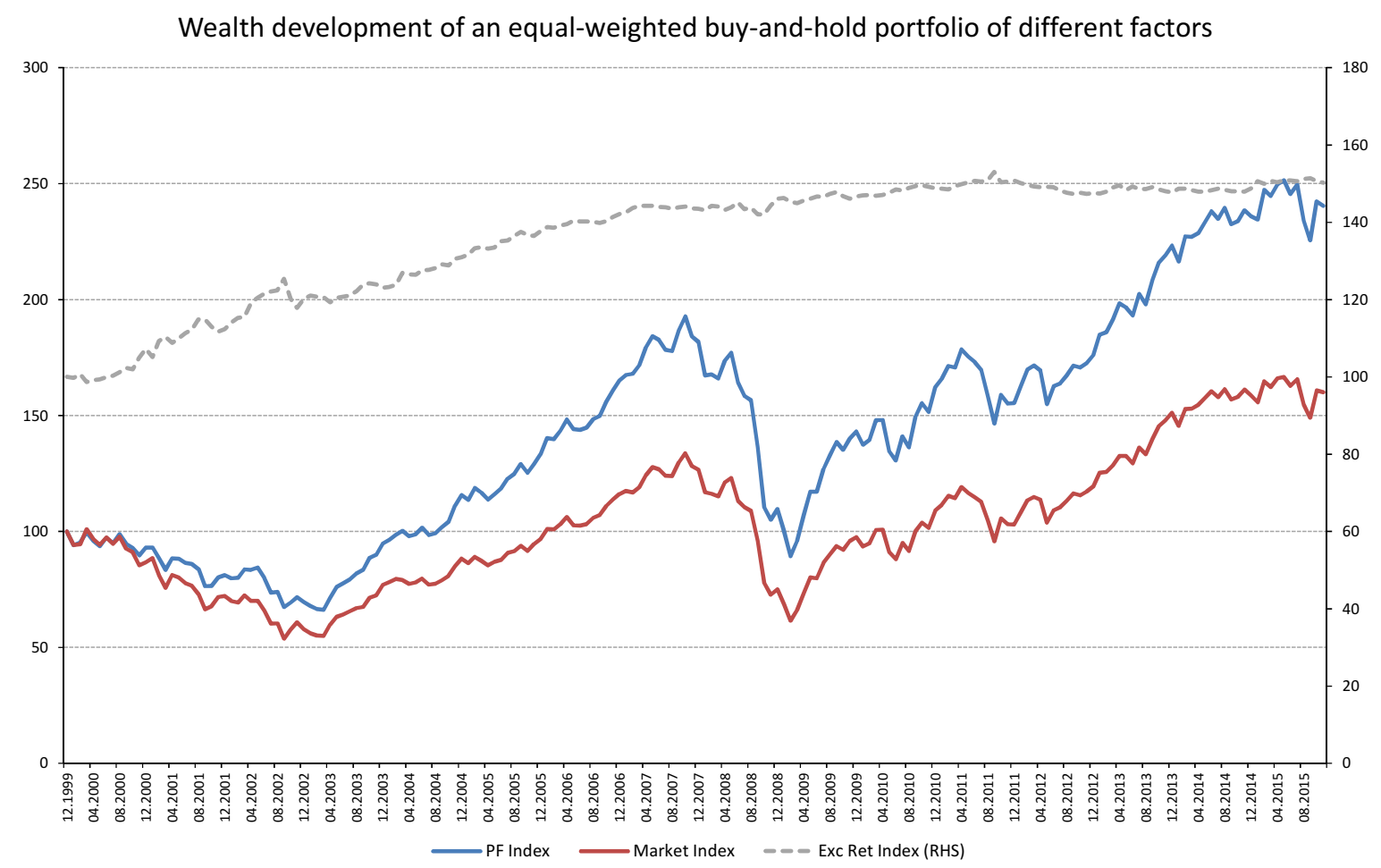

(Source: Bloomberg, own calculations)

Figure 8. Wealth development of an equal-weighted buy-and-hold portfolio of different factors (from 31.12.1998 until 30.11.2015)

error) is with $3 \%$ relatively low leading to an outperformance of the portfolio divided by information ratio (defined as the its tracking error) of 0.8 . 
10. CONCLUSION AND OUTLOOK FOR FUTURE RESEARCH

Given its versatility and applicability to improve the construction and risk-adjusted performance of portfolios, smart beta respectively factor-based investing has become an increasingly important investment approach for investors. Ongoing product development has opened the door for institutional as well as private investors looking to fine-tune their investment strategies by taking advantage of certain market inefficiencies through factor-driven strategies.

Unlike other recent academic articles on factor investing (Amenc et al., 2014; Koedijk et al., 2016; Laborda et al., 2016; Perchet, et al., 2014), this article does not aim at developing sophisticated trading models on factor investing. Our goal is to show that any institutional and private investor can already benefit from enhanced returns compared to the market index and from the diversification potential by investing in a broad basket of different traditional risk factors through already existing investment vehicles such as cost-efficient exchange traded funds (ETFs). This article is not only a homage to the classical risk factors and their developers but also an illustration that the increasing usage of factor-based investment strategies in the recent years represents the acknowledgement by the investment community to reap those fruits whose ground was set decades ago.

New investment topics arise in the academic literature such as the superiority of the private sector over the public sector companies with respect to productivity and profitability (Mijic et al., 2015) as well as the firm's growing orientation towards corporate social responsibility (Karabasevic et al., 2016). Future research might include the analysis of these new potentially profitable investment strategies to examine whether they are able complement and expand the traditional risk factors presented above (value, size, quality, momentum, low volatility) and whether they also constitute systematic risk premia.

\section{References}

Amenc, N., Goltz, F., Lodh, A., \& Martellini, L. (2014). Towards smart equity factor indices: Harvesting risk premia without taking unrewarded risks. Journal of Portfolio Management, 40, 106-122.

Ang, A., Goetzmann, W.N., \& Schaefer, S. (2009). Evaluation of active management of the Norwegian Government Pension Fund - Global Report to the Norwegian Ministry of Finance.

Asness, C., Frazzini, A., \& Pedersen, L. (2014). Quality minus junk. AQR Working Paper.

Baker, M., Bradley, B., \& Wurgler, J. (2011). Benchmarks as limits to arbitrage: understanding the low-volatility anomaly. Financial Analysts Journal, 67, 40-54.

Banz, R.W. (1981). The relationship between return and market value of common stocks. Journal of Financial Economics, 9, 3-18.

Fama, E.F., \& French, K.R. (1992). The cross-section of expected stock returns. Journal of Finance, 47, 427-465.

Fama, E.F., \& French, K.R. (1993). Common risk factors in the returns on stocks and bonds. Journal of Financial Economics, 33, 3-56.

Frazzini, A., \& Pedersen, L.H. (2013). Betting against beta. Working Paper, NYU Stern School of Business.

Glushkov, D. (2015). How smart are 


\title{
ИНОВАТИВНИ ТРЕНДОВИ ИНВЕСТИРАҢА: ИНВЕСТИРАЊЕ БАЗИРАНО НА ФАКТОРУ
}

\author{
Sanja Centineo, Santo Centineo
}

\section{Извод}

Овај чланак показује да може проћи дужи временски период док истраживања знања пронађу своју примену у пракси и буду дисеминирана као иновација тренда. Такав пример је инвестирање базирано на фактору. Иако је имало своје корене у развоју деведесетих година, требало је више од две деценије док је овај приступ откривен од стране инвестиционе заједнице. Циљ овог чланка је да подсети на дефинисања факторског инвестирања, презентује његов историјски развој и мотивацију његовим недавним пробојем и актуелним трендом у инвестиционој пракси (познат такође под појмом "Smart beta“). Чланак је усмерен на упознавање са овим инвестиционим приступом из практичне перспективе и истицање његове диверзификационе предности у портфолио контексту с потенцијалом да надмаши тржиште на бази прилагођавања ризику.

Кључне речи: „Smart beta“, фактори ризика, тржишне аномалије, диверзификација, ефикасно улагање

smart beta ETFs? Analysis of relative performance and factor exposure. Working Paper, WRDS/University of Pennsylvania.

Haugen, R.A., \& Heins, A.J. (1972). On the evidence supporting the existence of risk premiums in the capital markets. Working Paper, University of Wisconsin.

Haugen, R.A., \& Heins, A.J. (1975). Risk and the rate of return on financial assets: Some old wine in new bottles. Journal of Financial and Quantitative Analysis, 10, $775-784$.

Jegadeesh N., \& Titman, S. (1993). Returns to buying winners and selling losers: Implications for stock market efficiency. Journal of Finance, 48, 65-91.

Jensen, M.C. (1968). The performance of mutual funds in the period 1945-1964. Journal of Finance, 23, 389-416. Karabasevic, D., Paunkovic, J., \& 13-37.
Stanujkic, D. (2016). Ranking of companies according to the indicators of corporate social responsibility based on SWARA and ARAS methods. Serbian Journal of Management, 11 (1), 43-53.

Koedijk, K.G., Slager, A., \& Stork, P. (2016). Investing in systematic factor premiums. European Financial Management, 22, 193-234.

Laborda, J., Laborda, R., \& Olmo, J. (2016). Investing in the size factor. Quantitative Finance, 16, 85-100.

Lakonishok, J., Shleifer, A., \& Vishny, R. (1994). Contrarian investment, extrapolation and risk. Journal of Finance, 49, 1541-1578.

Lintner, J. (1965a). The valuation of risk assets and the selection of risky investments in stock portfolios and capital budgets. Review of Economics and Statistics, 47, 
Lintner, J. (1965b). Security prices, risk and maximal gains from diversification. Journal of Finance, 20, 587-615.

MarketStrategies International (2015). The Evolution of Smart Beta ETFs. Available

https://www.invesco.com/static/us/investors/ contentdetail? contentId $=818 \mathrm{a} 00 \mathrm{bb} 8885 \mathrm{c} 410$ VgnVCM100000c2f1bf0aRCRD\&dnsName $=\mathrm{us}$

Mijic, K., Jaksic, D., \& Berber, N. (2015). The analysis of productivity and profitability in the CEE region: Focus on the private and public sector. Serbian Journal of Management, 10 (2), 215-224.

Mossin, J. (1966). Equilibrium in a capital asset market. Econometrica, 35, 768-83.

Perchet, R., de Carvalho, R.L., \& Moulin, P. (2014). Intertemporal risk parity: A constant volatility framework for factor investing. Journal of Investment Strategies, 4, 19-41.

Sharpe, W.F. (1964). Capital asset prices: A theory of market equilibrium under conditions of risk. Journal of Finance, 19, 425-42.

Towers Watson (2015). The 500 largest asset managers. Available at https://www. towerswatson.com/en/Insights/ICT y p e s / S u r v e y - R e s e a r c h Results/2015/11/The-worlds-500-largestasset-managers-year-end-2014 